\title{
Legal protection of the underwater cultural heritage: lessons from the Titanic
}

\author{
by Sarah Dromgoole
}

\begin{abstract}
The subject of the legal protection of the underwater cultural heritage has a higher profile today than it has ever had and in many ways this is largely due to the discovery of the remains of RMS Titanic in 1985 and subsequent developments in respect of that wreck. The following paper, representing the text of a lecture delivered at the Institute of Advanced Legal Studies in June 2005, charts the history of the subject and considers some of the lessons that can be learnt from developments in respect of the Titanic. One or two issues of an ethical nature are also explored.
\end{abstract}

\section{BACKGROUND}

A wareness of the potential for finding archaeological remains beneath the sea arose in the 1950 s and

1960s, when self-contained underwater breathing apparatus (SCUBA) became widely available and recreational diving became a popular activity. From the 1960s through to the 1980s, the focus of attention was on shallow coastal waters and many countries introduced domestic legislation during this period to protect underwater cultural heritage $(\mathrm{UCH})$ in their territorial seas. At this time marine archaeology was very much a nascent discipline. The initial focus was largely on shipwrecks, and on shipwrecks of some considerable age. The UK's Protection of Wrecks Act 1973 was fairly typical of the type of legislation enacted in this period. It was designed to protect shipwrecks and the vessels designated under the Act in its early years were all several hundred years old. For example, the Tudor warship Mary Rose was one of the first wrecks afforded designated status under the Act. Although a substantial part of her hull was recovered in the early 1980s, a significant amount of material still lies in the Solent and the site remains protected to this day.

As the discipline of marine archaeology developed and matured, awareness grew of the potential breadth of historical remains lying beneath the seas. In the UK it is now possible to protect a wide variety of archaeological remains in territorial waters by scheduling them under the Ancient Monuments and Archaeological Areas Act 1979 (s 53). Ideas about how old something must be to qualify as being of "historical" or "archaeological" significance have also changed dramatically in recent years - demonstrated not least by changing attitudes to the question of whether or not the Titanic merits protection - and two or three twentieth century wrecks are now designated under the Protection of Wrecks Act. Increasingly, education is recognised as the key to successfully controlling the activities of recreational divers and amateur souvenir hunters. Their natural enthusiasm can be harnessed in many different ways to provide positive benefits for the $\mathrm{UCH}$. The UK is leading the way in showing how this can be done, for example through the "Adopt a Wreck" and "Diving for a Purpose" schemes sponsored by the Nautical Archaeology Society.

In 1985 the focus of attention shifted dramatically away from coastal waters. In that year the remains of the Titanic were discovered, lying at a depth of 2.5 miles and more than 300 miles off the coast of Newfoundland. Her hull was split in two and the hull sections were surrounded by an extensive debris field. The main purpose of the expedition that found the wreck was to test the capabilities of a new generation of deepwater exploration vehicle. The technological advances signalled by the discovery have resulted in the development of what is today a significant industry in deepwater salvage. With the aid of modern hydrographic surveying equipment (in particular, side-scan sonar, sub-bottom profiling and bathymetric survey) it is possible to locate wrecks lying on or beneath the ocean floor fairly easily from surface vessels and virtually all of the ocean floor, barring the deepest of ocean trenches, is now accessible using both manned and unmanned submersibles. As a result, there is now a small - but extremely well-equipped - band of professional treasurehunters who are embarked on a systematic process of locating and recovering valuable cargoes from shipwrecks. To use their own term, they are "harvesting" the world's oceans of bullion, gold and silver coins, jewellery and porcelain. 
While it can cost several million dollars to locate and recover material, the potential rewards are enormous. For example, in 2004, gold and silver coins reportedly worth in the region of $\$ 75$ million were recovered from the SS Republic, a Civil-war wreck lying approximately one-third of a mile deep 100 miles off the coast of Georgia (US). One of the coins alone (a Liberty Double Eagle) fetched $\$ 66,000$ at auction in April 2005. The same organisation apparently has five high-value "targets" within its sights in the Western Mediterranean, not to mention a contract with the UK government for the recovery of coins from HMS Sussex, a seventeenth century British warship. The coins on the Sussex alone are reputably worth anywhere from several hundred million to a billion dollars or more (for further details of the Sussex contract, see Dromgoole, 2004).

In light of these developments, attention has now shifted from shallow coastal waters to waters beyond territorial limits, and from the threat posed by amateur divers to that posed by professional treasure-hunters. Beyond the 12mile limit the situation is governed largely by the traditional principle of freedom of the high seas and salvage law. As a result, in many cases there is little to stop treasure hunters from recovering material and taking it ashore in a jurisdiction of their choice. Generally speaking, that jurisdiction is the US. The function of the law of salvage is both commercial and economic: it is designed to encourage salvors to recover maritime property and return it to the "stream of commerce". Notably, the International Salvage Convention 1989 does not exclude the UCH from its scope of application, although it is possible for States to reserve the right not to apply salvage law to such material (by virtue of Art 30(1)(d)).

The UN Convention on the Law of the Sea 1982 foresaw the threat posed by treasure hunting to some degree and includes two provisions relating specifically to the UCH, Articles 149 and 303. While these articles are generally regarded as being entirely inadequate to protect the $\mathrm{UCH}$, they do have some value. Most significantly, Article 303(1) imposes an obligation on all 149 States that are party to the Convention to protect "objects of an archaeological and historical nature" in all sea areas. It also requires that they co-operate together for that purpose. Useful provision is also made for the contiguous zone, which extends out to 24-miles from coastal baselines (see Article 303(2)), and somewhat less useful provision is made for the deep seabed, which the Convention refers to as the 'Area' (see Art 149). There is, however, a "gap" in the specific provision made by the Convention and that is in respect of the continental shelf. The Titanic - situated right at the edge of Canada's outer continental shelf - falls in the gap.

One of the positive aspects of the Law of the Sea Convention is that its provisions appear to leave open the door to a specific international instrument on the $\mathrm{UCH}$ (see Art 303(4)). An initiative to draft such an instrument, started by the International Law Association (ILA) in 1990, was given greater impetus by developments in respect of the Titanic following its discovery. In particular, a profit-making company called RMS Titanic Inc. (RMST) had been recovering artefacts from the debris field over a period of several years and in 1994 was awarded exclusive salvage rights by a US admiralty court (924 F. Supp. 714). This focused attention on the inadequacy of international law, and the Law of the Sea Convention in particular, for protecting wreck sites beyond territorial limits. The ILA initiative was therefore taken up - with some sense of urgency - by UNESCO and in 2001 the UNESCO Convention on the Protection of the Underwater Cultural Heritage was adopted. The Convention is designed to provide a comprehensive legal regime for regulating the activities of treasure-hunters in international waters (for details, see Dromgoole, 2003 (a) and (b)). However, it also makes some useful provision for territorial waters (Article 7), and for activities that incidentally affect the UCH, such as mineral exploitation, pipeline and cable-laying, etc. (Article 5).

The UNESCO Convention enshrines fundamental archaeological principles, including the prime archaeological mantra that protection in situ should be the first option to be considered in determining the future of a site. Intrusive activity should be permitted only where scientifically justified, in other words either to advance the cause of science, or where a site is under some sort of physical threat. Perhaps most significantly, the Convention incorporates benchmark standards for archaeological good practice in Rules set out in an Annex, which are based on a Charter produced by the International Council for Monuments and Sites (ICOMOS) in 1996.

While many would have liked the Convention to exclude $\mathrm{UCH}$ from the law of salvage altogether, it does not expressly do so (see Art 4), although the practical implications of its approach mean that salvage law will be largely irrelevant. Another key question that those drafting the Convention had to consider was whether or not they should prohibit commercial exploitation of the $\mathrm{UCH}$ and, in particular, the sale of recovered artefacts. The final text deals with this issue by effectively banning sale where it will lead to the irretrievable dispersal of material from a particular site, but leaving room for the sale of an entire assemblage, or perhaps significant parts of an assemblage, to museums or similar institutions (Rule 2 of the Annex).

Unfortunately, the deeply entrenched opposition of the major maritime States to any extension of coastal State jurisdiction beyond that established in the Law of the Sea Convention meant that the drafters at UNESCO were obliged to resort to very complex mechanisms for controlling activities beyond the 24-mile contiguous zone. These measures are heavily dependent for their effectiveness upon a large number of States participating in the Convention's regime and co-operating together effectively. To a large extent the mechanisms are reliant on 
States Parties exercising jurisdictional rights that they already possess: in particular the right of a State to govern the activities of its own nationals and flag vessels, wherever they might be; and also the right of a State to control the use of its own territory, including its ports and territorial waters. Whether the regulatory scheme set out in the Convention is really workable remains to be seen.

At present, it is difficult to predict what the future of the Convention will be; indeed, whether it will have a future at all. Although four years have passed since its adoption by UNESCO, the ratification process has been painfully slow. Indeed, to date only five States have ratified: Panama, Bulgaria, Croatia, Spain and Libya. Nonetheless, 87 States voted in favour of the adoption of the Convention (with 4 votes against and 15 abstentions) and therefore it seems likely that the Convention will eventually gain the 20 ratifications required to bring it into force. The really serious problem the Convention faces is that a number of key maritime States maintain serious objections to its text and are unlikely to ratify it in the foreseeable future. These include: the US, UK, France and Russia. The support of these States is crucial to the success of the Convention because their nationals and flag vessels possess the technology to undertake deepwater salvage. Unless they participate in the regime, it will leave huge holes in the Convention's protective framework.

The UK has expressed two specific objections to the Convention: one relates to the question of the significance of the remains that States will be required to protect and the other relates to the question of sunken warships. As far as the first objection is concerned, the UK - along with other common law jurisdictions - has traditionally identified and designated for protection aspects of the cultural heritage that are of special significance. This approach can be seen in its legislation in respect of ancient monuments and listed buildings, and regulations to control the export of works of art, as well as the Protection of Wrecks Act. The latter, for example, affords protection to wrecks deemed to be of "historical, archaeological or artistic importance" (emphasis added). The UNESCO Convention, on the other hand, requires that States protect "all traces of human existence... which have been...under water...for at least 100 years", subject only to those traces having a cultural, historical or archaeological "character"'. It therefore adopts what is referred to as a "blanket" approach (often seen in civil law jurisdictions), protecting essentially all material - of whatever importance - over a certain age. The UK government is of the view that it could not fulfil a duty to protect all such material in light of the vast number of shipwrecks lying off UK shores. Whether this is the case or not is debatable, depending at least partly on exactly what action would be required to fulfil its duties under the Convention. To some extent this is a matter of interpretation.

The objection with respect to sunken warships is almost certainly a much more serious obstacle. The UK and many other maritime States take the position that their warships and other State vessels retain sovereign immunity even after they have sunk. For this reason they argue that they have exclusive sovereignty over their State vessels wherever they lie and that no-one may interfere with them without the express permission of the sovereign flag State. The US has recently sought to reinforce its position in this respect by enacting the Sunken Military Craft act of 2004 (formally known as Title XIV of the FY2005 National Defense Authorization Act), which reiterates its claims in respect of its sunken State vessels (and aircraft). These maritime States believe that the provisions of the UNESCO Convention interfere with their exclusive sovereignty because in certain circumstances they afford coastal States the power to determine the future of State vessels without the agreement of the flag State. A reading of the relevant provisions of the Convention (Articles 7(3), $10(2), 12(7))$ shows that they have a point. Unfortunately, this essentially technical objection, almost certainly capable of resolution if there had been more time for negotiation, is likely to result in a number of important States failing to ratify the Convention.

\section{LESSONS FROM THE TITANIC}

Despite the present uncertainty concerning the future of the UNESCO Convention, developments in respect of the Titanic over the last twenty years can teach us some generally encouraging lessons. The first, and perhaps most important, lesson that we can learn is that the UNESCO Convention is already having a significant impact on law and policy, long before it comes into force or becomes widely applicable. Moreover, it is having such an impact even in States that hold specific objections to the Convention.

In 2000, the US, UK, France and Canada finalised the text of an inter-State agreement for the protection of the Titanic (for a detailed analysis of the Agreement, see Dromgoole, 2006). To date the agreement has been signed by the US and UK, and it is expected that France and Canada will follow suit. It will come into force after the US Congress has passed implementing legislation, which may take some time. The Agreement is designed to protect the "exceptional international importance" of the wreck, as well as its sanctity as a gravesite (Art 2). Inter-State agreements of this sort have to work within the confines of existing international law and the Titanic Agreement relies on existing principles of international jurisdiction to create a protective regime for the wreck. It provides that States Parties must regulate the activities of their own flag vessels and nationals at the site itself, and must also prohibit activities in their territory, including their ports, territorial waters, etc., that are inconsistent with the Agreement. Essentially these are its two "control" devices. If all those States whose nationals have the technology to access the site, plus all those States in the general geographical vicinity of the site, were persuaded to sign the Agreement (which 
is the intention of the negotiating parties) these control devices could be very effective.

What is striking about the Agreement is that it bears a remarkable degree of similarity to the UNESCO Convention. The two instruments were drafted at much the same time and the UNESCO initiative clearly had a very significant influence on the thinking of those involved in negotiating the Titanic Agreement. The general principles and objectives of the UNESCO Convention are echoed in the Agreement. They include the principle that the UCH should be preserved for the benefit of humanity and that States must co-operate to achieve that purpose. The Titanic Agreement enshrines the principle of protection in situ, allowing recovery only where scientifically justified and incorporates Rules in an Annex, which very closely reflect the Rules in the Annex to the UNESCO Convention. The policy on commercial exploitation is also essentially the same, with the sale of artefacts on the open market effectively prohibited. The similarity between the two instruments is remarkable given that three of the four States that negotiated the Titanic Agreement hold objections to the Convention (the UK, US and France). Apart from demonstrating that the Convention is already having an impact, it demonstrates the degree to which even the maritime States support the general principles and objectives of the Convention.

Although this may be the most striking example of how the UNESCO Convention is having an impact, there are other examples around the world. In particular, a number of States are considering making use of mechanisms for protecting sites beyond territorial limits that have some basis for legitimacy in the Law of the Sea Convention, but which have been highlighted - and in some cases developed - by the UNESCO Convention. For example, Italy and the Netherlands either have, or plan to, extend their domestic legislation in respect of the $\mathrm{UCH}$ to the 24mile contiguous zone (see Article 8 of the UNESCO Convention). In the UK consideration is being given to affording some form of protection to the $\mathrm{UCH}$ indirectly as a result of measures to protect the country's sovereign natural resources on its continental shelf (see Art 10(2) of the UNESCO Convention). It is possible that the Marine Bill, which is part of the government's forthcoming legislative programme, will make provision in this respect. Whatever the fate of the Convention, it seems likely that its general principles, and the Rules in its Annex, will be applied increasingly in domestic legislation and international agreements of various sorts, so that eventually they become a global standard. This in itself would be no mean achievement.

The Titanic Agreement is itself an example of one of the mechanisms that the UNESCO Convention highlights and encourages States to use - to provide protection for the UCH. Article 6 of the Convention encourages States to enter into bilateral, regional or other multilateral agreements, or to develop existing agreements, for the "preservation of UCH", the idea being that in certain circumstances such agreements may afford more effective protection than the Convention itself. The Titanic Agreement demonstrates that some major maritime States are prepared to utilise this mechanism. In fact, since the late 1980s both the US and the UK have negotiated a number of such agreements in order to protect historically significant wreck sites. Generally speaking these agreements have been used to avert a potential jurisdictional conflict in circumstances where a sunken warship or other State vessel of one State has been discovered in the territorial waters of another. The most recent example is the agreement of 2003 between France and the US for the protection of de Salle's vessel, La Belle, which sank off Texas in 1686. The Titanic Agreement is unusual in that it relates to a site in international waters. In such cases a plurilateral -rather than a bilateral agreement will usually be required.

Agreements for the protection of specific wreck sites are usually made after a site has been discovered and may not 'bite' until serious interference has taken place. This is graphically illustrated in the case of the Titanic. Despite its depth, in the two decades since its discovery numerous expeditions to the site have taken place for the purpose of recovering artefacts, providing public tours, taking film and photographs and conducting scientific experiments. During this time, more than 6,000 artefacts have been removed from the debris field and significant features of the ship have disappeared or collapsed. The manoeuvring of submersibles has also had a visible impact on the hull sections. After Robert Ballard, joint-leader of the expedition that found the wreck, returned to the site in 2004, he reportedly said that it had been 'irreversibly damaged' (Washington Post, 19 June 2004). Arguably, therefore, the agreement for the protection of the site comes far too late in the day.

Nonetheless, inter-State agreements have the potential to be used on a much broader scale than to date and to take effect at a much earlier point in time, in other words before sites are discovered. Article 6 of the UNESCO Convention specifically refers to the possibility of regional agreements, whereby all the States in a particular region agree to control the activities of their own nationals, and the use of their territory, in respect of any activities in the region. Such agreements could be particularly effective in enclosed and semi-enclosed sea regions, such as the Mediterranean, the Baltic and perhaps even in the East and South East China Seas. A further possibility would be for two States to negotiate a bilateral agreement whereby each agrees to control inappropriate activities by its own nationals or in its own waters in respect of the sunken warships and State vessels of the other. In light of their common perspective on such matters, such an agreement would seem an obvious route for the US and UK to pursue. Although the US has been promoting inter-State agreements as an alternative to the UNESCO Convention, such agreements 
should not be seen as a threat to the Convention. Provided they adopt the same principles and standards, they can operate alongside the Convention and have the potential to be an extremely useful and flexible device.

A further lesson that we can learn from the recent history of the Titanic is that the law of salvage, at least as applied in the US, is gradually reforming itself to perform a cultural - as well as commercial and economic function. In light of the fact that the US is the jurisdiction of choice for many treasure hunters, the development of US judicial thinking on this topic is of crucial significance. Since 1994, a US District Court in Norfolk, Virginia, overseen by the Fourth Circuit Court of Appeals, has presided over an extraordinary in rem action in respect of the Titanic. Over the eleven-year period that the action has been on-going, there have been numerous district court hearings, along with two by the Court of Appeals. The reports make fascinating reading.

As mentioned earlier, in 1994 the district court awarded RMST exclusive salvage rights, in other words conferred upon it the status of "salvor-in-possession". In order to maintain this status, RMST has mounted regular expeditions to the site and recovered thousands of artefacts. It has also been required to submit periodic reports of is activities to the district court in order to demonstrate that it is undertaking the salvage with due diligence. In return, the court has protected the exclusivity of RMST's rights by issuing injunctions against the activities of competing salvors (924 F Supp 714, 1996 WL 650135, 9 F Supp 2d 624). Since the Titanic lies in international waters, outside the territorial jurisdiction of the US admiralty court, in order to exercise jurisdiction over the site the court asserted "constructive in rem" jurisdiction. It did this on the basis that - although the wreck itself was not within its jurisdiction - part of the wreck (a wine decanter) had been brought within the jurisdiction. This basis for jurisdiction was both confirmed, and extensively discussed, by the Fourth Circuit Court of Appeals (RMS Titanic Inc v Haver, 1999). Of course, the extra-territorial location of the wreck means that any injunctions issued by the court are effective only against US nationals and flag vessels, not against the "whole world".

A significant factor that the district court has taken into account, both in granting RMST exclusive rights and in subsequently protecting those rights, has been that the organisation from the outset manifested an intention not to sell any artefacts raised, but instead to keep the artefacts together as a collection for exhibition to a paying public. Both the district court and the Fourth Circuit Court of Appeals have recognised that there is a public interest in maintaining the archaeological integrity of such a unique historical wreck and believe that such interest is served by ensuring that the artefacts are properly conserved and kept together as a publicly accessible collection. Although it appears that in recent years RMST has found it difficult to fund the huge costs of its deepwater salvage work solely by exhibition revenues, it has been precluded by court order from selling individual artefacts (with the exception of pieces of coal) (286 F.3d 194).

In the last year or so, it seems that RMST has been keen to obtain at least an interim salvage award, but the district court appears to have been equally keen to postpone making such an award because it fears it will lose control of the artefacts if it does so. To all intents and purposes, the district court has been managing activities on the site and determining the disposition of material recovered from the site. It would argue that it has prevented free-for-all looting of the site, ensured that the artefacts are carefully recovered and properly conserved, and that they are kept together and made available for public exhibition.

While the unique public interest in the Titanic has certainly been a factor in the attitude and approach of the US federal courts in this particular case, the principles they have developed and expounded over the years will undoubtedly be applied in future cases. In fact, it is not only in the case of the Titanic that archaeological considerations have already been taken into account. Litigation in respect of the Central America in the early 1990s (see 974 F.2d 450) led to recognition of efforts taken by a salvor to preserve the archaeological "provenance" of material as a seventh factor to be taken into account in determining the level of a salvage award (the six traditional factors having been established by the Supreme Court in The Blackwall, 1870).

It is clear then that salvage law, at least as applied in the US, is gradually being modified to take into account archaeological considerations. Nonetheless, salvage law however "modified" - will always be flawed in its application to $\mathrm{UCH}$. This is because the fundamental purpose of salvage law - to encourage recovery - is antithetical to the foremost archaeological principle of protection in situ. Furthermore, the judiciary's control over a site will only begin after material has been recovered and brought ashore. From an archaeological point of view, any interference with a site is destructive: as the archaeological mantra goes, "excavation equals destruction" (and this includes proper archaeological excavation). What is required is a system whereby management decisions can be made before any interference takes place. Furthermore, the decisions should be taken by executive agencies with professional archaeological expertise, rather than by judges, however well-meaning. The purpose of the UNESCO Convention is to introduce such a system. Nonetheless, until such time as the Convention becomes widely applicable (which may be many years), the process of modifying salvage law will be of crucial significance.

The late Mr. Geoffrey Brice QC put forward the suggestion that there should be an archaeological protocol to the International Salvage Convention, making special provision for the application of salvage law to maritime 
cultural property (Brice, 1996). If at some point in the future the UNESCO Convention appears to be a dead letter, this proposal would undoubtedly be worth pursuing.

\section{ETHICAL MATTERS}

In considering how best to regulate interference with the $\mathrm{UCH}$, several questions of an ethical nature need to be addressed. While the Titanic probably does not teach us any particular lessons about them, it does provide us with a fairly unique illustration of the issues and demonstrates the complexities that may arise in framing legal instruments in this field.

One of the questions facing the drafters of the UNESCO Convention was whether they should allow some room for commercial participation in the scheme they were creating. In other words, should commercial operators be recognised as legitimate "users" of the underwater cultural "resource" (as is the case, for example, in the US Abandoned Shipwreck Act of 1987)? As mentioned earlier, the drafters concluded that commercial exploitation - in so far as it involved the sale of artefacts on the open market - was unacceptable, since it would lead to the irretrievable dispersal of material. However, the Convention does not outlaw other forms of commercial exploitation.

Since its discovery, the Titanic has been the subject of commercial exploitation in forms never previously seen. This is partly because of the fame of the wreck and partly because (unlike most other wrecks that have been targeted by commercial operators) the Titanic is not a treasure ship. Generally speaking, neither her cargo, nor the personal possessions of passengers and crew, had any great intrinsic value. The Cargo Manifest, for example, shows that she was carrying a remarkable range of largely perishable general cargo, mainly comprising all sorts of foodstuffs, clothing materials and other types of household goods and consumables. While the sale of the many thousands of mundane artefacts recovered from the site would undoubtedly raise a considerable sum of money because of the premium that the Titanic "legend" places on them, it seems that the salvor, RMST, calculated that even more money could be earned by creating a permanent collection of artefacts available for public exhibition. The recovery of artefacts for exhibition has therefore been the main form of commercial exploitation of the site. However, since the exclusivity of RMST's salvage rights does not extend to merely visiting the site, filming it, or taking photographs (RMS Titanic Inc $v$ Haver, 1999), other commercial operators have also been exploiting the site, in particular, by conducting public tours (the price of a "luxury" tour, including a 12-hour "adventure dive" in a submersible is in the region $\$ 36,000)$.

An interesting feature of the Titanic Agreement is that it seeks to regulate only entry into the hull sections of the vessel and activities "aimed at" the artefacts in the debris field. This means that merely visiting the site on a "look but don't touch" basis will not require authorisation. On the face of it, this may seem reasonable enough. However, when activities are motivated by profit, there is always a risk that they may result - intentionally or unintentionally - in intrusive interference. As circumstances in respect of the Titanic illustrate, even tour operators and film-makers may inadvertently cause physical damage simply by attempting to get as close as possible to the site to obtain the best view, or camera shots.

The reason for the absence of any regulation of these activities in the Agreement is that one of its main underlying policies is the promotion of public access. While some "purist" archaeologists would argue that any form of commercial exploitation of $\mathrm{UCH}$ is unacceptable because of the potential damage it might cause, there is no doubt that commercially funded activities can open up sites (especially deepwater sites) to the general public in ways that few publicly funded organisations could afford. Nonetheless, surely they require some form of regulation? Under the terms of the UNESCO Convention, for example, such activities would almost certainly have to be licensed, and conditions could thereby be imposed upon them. The fact that the Titanic Agreement does not provide for this is surprising.

A further issue arises from the question of public access. To what extent, if at all, should such access be permitted where a vessel sank with loss of life, especially in relatively recent times? More than 1,500 passengers and crew lost their lives when the Titanic sank in 1912. Close relatives of the victims will certainly still be living. There is some considerable tension in the Titanic Agreement between its two aims: to protect the sanctity of the site as a maritime memorial and to safeguard the public interest in the site as one of exceptional international significance. In practice, these two interests are extremely difficult to reconcile. For this reason, the protective scheme set out in the Agreement incorporates a fundamental compromise. On the basis that if there are any human remains on the site, they are likely to be found in the hull (where many people were trapped) recovery of artefacts from within the hull is precluded even though there is archaeological (and, no doubt, public) interest in such recovery. The debris field, on the other hand (where no human remains have been found to date) will be open to exploitation, subject to appropriate recovery methodology and disposition of artefacts.

Whether this scheme draws an appropriate balance between public interest and the sanctity of the site must be questionable. In particular, it seems surprising that any entry to the hull is permissible. Surely even entry to film the interiors invades the sanctity of what is after all a mass grave, whether or not human remains are actually found? Furthermore, one might also question whether the recovery of artefacts from the debris field should be permissible. Some of those artefacts will be the personal possessions of people who died in the disaster, possibly even items that they were wearing at the time of their 
death. The UNESCO Convention provides that any activities must avoid the "unnecessary disturbance of human remains or venerated sites" (Rule 5 of the Annex). Arguably, the Titanic Agreement does not provide for this.

While the sinking of the Titanic is the most famous maritime disaster, there are plenty of other cases where there has been great loss of life at sea, especially as a result of war. Lying off the coast of Jutland in Denmark are a number of British and German vessels that were lost in the Battle of Jutland in World War I, with many thousands of sailors on board. Several of these wrecks were located in 2000 and 2001, and are now the subject of attention from Danish and other divers. There are also two or three German vessels lying in Gdansk Bay in Poland, which were lost towards the end of World War II carrying several thousand refugees from German East Prussia along with all their valuables. In recent years these too have attracted the attention of divers. In both cases there is currently no legal protection for the sites, presumably because of various political sensitivities and uncertainty about the question of jurisdiction. In cases such as these, inter-State agreements may well be the best way forward. However, the balancing of public interest in access and the preservation of the sanctity of the site will need to be addressed on a case-bycase basis. Arguably, the more recent the disaster, the less justification there is for public access. In the case of the passenger ferry Estonia, which sank in 1994 with the loss of approximately 800 lives, there is an inter-State agreement that seeks to criminalise any activities disturbing the peace of the site.

\section{CONCLUDING REMARKS}

There are some that argue that the Titanic has been diverting attention and resources from other far more important underwater historical sites. While there may be some truth in this, the argument ignores the fact that the wreck is a major, relatively recent, gravesite. For this reason alone the author believes that the site merits legal protection. However, whatever one's views about this, there is no doubt that the discovery of the Titanic in 1985 and subsequent developments in respect of the wreck have focused international attention on the subject of the legal protection of the $\mathrm{UCH}$ in a way that no other shipwreck could. Furthermore, they have taught us some very valuable lessons.

\section{International instruments}

Agreement between the Republic of Estonia, the Republic of Finland and the Kingdom of Sweden regarding the M/S Estonia, 1995

Agreement between the Government of the United States of America and the Government of the French Republic regarding the Wreck of La Belle (Washington, 31 March 2003)
Agreement Concerning the Shipwrecked Vessel RMS Titanic (see Appendix to DTp Consultation on UK Implementation of the Agreement for the protection of the wreck of the RMS Titanic, 7 April 2003 (http://www.dft.gov.uk))

ICOMOS Charter on the Protection and Management of Underwater Cultural Heritage (1996)

International Salvage Convention 1989

UN Convention on the Law of the Sea 1982

UNESCO Convention on the Protection of the Underwater Cultural Heritage 2001

\section{UK statute law and statutory instruments}

Protection of Wrecks Act 1973

Ancient Monuments and Archaeological Areas Act 1979

Protection of Wrecks (M/S Estonia) Order 1999 (SI 1999, No. 856)

Protection of Wrecks (RMS Titanic) Order (SI 2003, No. 2496) (not yet in force)

\section{US statute law}

Abandoned Shipwreck Act of 1987

Sunken Military Craft act of 2004 (otherwise known as Title XIV of the FY2005 National Defence Authorization Act (Public Law No. 108-375, Oct. 28, 2004))

\section{US caselaw}

The Blackwall 77 US 10 Wall. 1 (1870)

Columbus America Discovery Group v The Unidentified, Wrecked and Abandoned Sailing Vessel (The Central America) 974 F.2d 450 (1992)

RMS Titanic Inc $v$ Wrecked and Abandoned Vessel, 924 F. Supp. 714 (ED Va May 10, 1996)

RMS Titanic Inc $v$ Wrecked and Abandoned Vessel, 1996 WL 650135 (ED Va, 1996)

RMS Titanic Inc $v$ Wrecked and Abandoned Vessel, 9 F Supp 2d 624 (ED Va, 1998)

RMS Titanic Inc v Haver, 171 F.3d 943 (4th Cir. (Va.) March 24, 1999)

RMS Titanic Inc $v$ Wrecked and Abandoned Vessel, 286 F.3d 194 (4th Cir. (Va.) April 12, 2002)

RMS Titanic Inc $v$ Wrecked and Abandoned Vessel, 323 F. Supp.2d 724 (ED Va Jul 02, 2004)

\section{Bibliography}

G. Brice, "Salvage and the underwater cultural heritage" 20 Marine Policy 337-342 
W. Dorsey, "Historic Salvors, Marine Archaeologists, and the UNESCO Draft Convention on the Underwater Cultural Heritage", paper delivered at Houston Marine Insurance Seminar 2000 (available at www.houstonmarineseminar.com).

S. Dromgoole, "An International Agreement for the Protection of the Titanic: Problems and Prospects" (2006) 37 Ocean Development and International Law (in press)

S. Dromgoole, "Murky waters for government policy: the case of a seventeenth century British warship and ten tonnes of gold coins", (2004) 28 Marine Policy 189-198

S. Dromgoole, "2001 UNESCO Convention on the Protection of the Underwater Cultural Heritage" (2003) 18 International Journal of Marine and Coastal Law 59-91 (a)

S. Dromgoole, "UNESCO Convention on the Protection of the Underwater Cultural Heritage 2001: Implications for Commercial Treasure Salvors" [2003] Lloyd's Maritime and Commercial Law Quarterly 317-340 (b)

P. Fletcher-Tomenius, P. O'Keefe, M. Williams, "Salvor in Possession: Friend or Foe to Marine Archaeology?" (2000) 9 International Journal of Cultural Property 263
C. Forrest, "Salvage Law and the Wreck of the Titanic: RMS Titanic v Haver" [2000] Lloyd's Maritime and Commercial Law Quarterly 1

P. O'Keefe, "Gold, Abandonment and Salvage: The Central America" [1994] Lloyd's Maritime and Commercial Law Quarterly 7

P. O'Keefe, Shipwrecked Heritage: A Commentary on the UNESCO Convention on Underwater Cultural Heritage (2002, Institute of Art and Law)

O. Varmer, "The Case Against the 'Salvage' of the Cultural Heritage" (1999) 30 Journal of Maritime Law and Commerce 279

\section{Dr Sarah Dromgoole}

Reader in Law, University of Leicester

Dr. Dromgoole has written extensively on the topic of law and the underwater cultural heritage. She is currently writing a monograph for Cambridge University Press on international law and the underwater cultural heritage and is editing a volume of essays, to be published by Martinus Nijhoff, providing national perspectives on the subject in light of the UNESCO Convention 2001. 